\title{
GENEZA PRAVICE DO UMETNE PREKINITVE NOSECNOSTI V NEKDANJI JUGOSLAVIJI
}

Ključne besede: umetna prekinitev nosečnosti, načrtovanje družine, svobodno odločanje o rojstvu otrok, liberalizacija zakonodaje, ustavna pravica

\section{Uvod}

Ženske poskušajo usmerjati in nadzorovati svojo reprodukcijo že od nekdaj. Z nastankom nacionalnih držav si je pravico o odločanju do umetne prekinitve nosečnosti vzela država in s svojo represivnostjo na takšen ali drugačen način uravnavala odločitve nosečih žensk.

Socialistični režimi srednje- in vzhodnoevropskih držav so socialno politiko razumeli kot pomemben instrument družbenega načrtovanja in nadzora. Vsak državljan je bil upravičen do nekaterih temeljnih socialnih pravic: do dela, prostega časa, zdravstvene oskrbe, varnosti v starosti in podobno. Naloga socialne politike je bila regulirati načine izvajanja teh pravic, medtem ko je obvladovala produktivno in zvesto delovno silo. Socialna politika je bila del družbenega načrtovanja, ki je odražalo politično ideologijo. Bila je tudi sredstvo za uvajanje ideološke zavezanosti socializma $\mathrm{k}$ enakosti spolov.

Z dekretom Vladimirja Iljiča Lenina novembra 1920 je Sovjetska zveza postala prva država na svetu, ki je legalizirala splav na zahtevo ženske v prvih treh mesecih nosečnosti. Po obdobju kriminalizacije, ki je sledilo leta 1936, je bil splav na zahtevo ponovno omogočen leta 1955, po Stalinovi smrti. Besemers (1980) ponuja možno razlago - legalizacijo splava razume ne le kot nekaj, kar je potekalo vzporedno s politično otoplitvijo, 
temveč kot nekaj, kar je njen neposreden, politično motiviran produkt. S to potezo so sovjetske oblasti pokazale svojo občutljivost do trenutnih družbenih problemov in naklonjenost permisivnejšim družbenim normam. Trend liberalizacije zakonodaje $\mathrm{v}$ zvezi $\mathrm{z}$ umetno prekinitvijo nosečnosti se je pričel v petdesetih letih dvajsetega stoletja, ko je večina socialističnih držav sledila sovjetskemu zgledu takoj (Bolgarija, Češkoslovaška, Romunija, Poljska in Madžarska) ali sčasoma (Jugoslavija in Nemška demokratična republika). Spremembe, ki so zajele te države, so za več kot desetletje prehitevale dogodke v zahodni Evropi (z izjemo skandinavskih držav) in Severni Ameriki. Kljub temu so socialistične politike reguliranja plodnosti ostale kontradiktorne. V večini držav so ženskam onemogočili ustrezno izobrazbo o sodobnih metodah preprečevanja nosečnosti in dostop do sodobnih kontracepcijskih sredstev, kar je povzročilo, da je bil splav sprejet kot edina možna oblika kontracepcije.

V članku bom prikazala razvoj politike na področju reguliranja umetne prekinitve nosečnosti v nekdanji Jugoslaviji. Poseben poudarek bo namenjen oblikovanju zakonodaje v Sloveniji. Postopna liberalizacija zakonodaje umetne prekinitve nosečnosti je v nekdanji Jugoslaviji, za razliko od nekaterih drugih srednje- in vzhodnoevropskih držav, potekala postopno, lahko bi celo rekli premišljeno ter sočasno $\mathrm{z}$ razvojem kontracepcijske službe in politiko načrtovanja družine.

\section{Obdobje kriminalizacije umetne prekinitve nosečnosti}

V vseh deželah, ki so se leta 1918 združile v Kraljevino Srbov, Hrvatov in Slovencev, je bila prekinitev nosečnosti prepovedana in opredeljena kot kaznivo dejanje. Kazen je doletela tako žensko, ki se je za splav odločila, kot tudi osebo, ki ga je izvedla. V Sloveniji se je o splavu prvič začelo javno govoriti leta 1929, ko je bila v Kraljevini Jugoslaviji uzakonjena medicinska indikacija za splav (Rožman, 2001, 115). Področje je urejal kazenski zakonik, ki je stopil v veljavo 27. januarja 1929 in ki v 173. členu dopušča prekinitev nosečnosti iz zdravstvenih razlogov. "Ne bo kaznovan zdravnik, ki noseči ženski ob predhodni najavi oblastem in na osnovi privolitve zdravniške 
komisije pravilno izzove prekinitev nosečnosti ali splav, da bi ji rešil življenje ali odpravil hudo nevarnost za njeno zdravje. «Po 171. členu zakonika je bila lahko ženska obsojena največ na tri leta zapora, vendar je smelo sodišče v posebno lahkih primerih kazen omiliti, »/.../ nezakonsko mater pa, če je sama odpravila plod, tudi oprostiti vsake kazni«. Oseba, ki je ženski ponudila sredstvo za uničenje zarodka ali ga je sama fizično odstranila, je bila kaznovana s strogim zaporom, kazen za zdravnika ali babico, ki sta za opravljen splav prejela denar, pa je bila pet let zapora. Prav tako sta bila z zaporom do enega leta kaznovana zdravnik ali babica, če sta že začeti splav končala in tega nista prijavila pristojnemu organu (172. člen). Kdor je plod odstranil proti volji ženske, je bil kaznovan z najmanj petimi leti zapora; kazen je bila enaka, če je ženska pri tem umrla (173. člen). Babicam je bilo prepovedano objavljanje in oglaševanje sredstev za splav ali podobnih storitev za odstranitev plodu. Vsakdo, ki je v javnosti ali zasebno ponujal odstranitev plodu za denar, je bil kaznovan s strogim zaporom do enega leta (174. člen).

Zaradi slabih razmer, v katerih so tedaj živele številne delavske družine, je bilo po mnenju A. Vode $(1998,202) » / . . . /$ brezsrčno siliti matere, da rode otroke, če jih ne morejo preživljati«. Pri tem je seveda treba poudariti, da so bile najbolj prizadete ženske iz nižjih socialnih slojev, premožnejše ženske pa so si splav lahko privoščile, seveda za ustrezno plačilo. Po podatkih A. Zalokarja je razvidno, da je bilo v letih 1920-1926 na Slovenskem zaradi splava v žensko bolnišnico sprejetih 25,2 odstotka žensk, od teh jih je umrlo 1,3 odstotka; leta 1930 je bilo zaradi splava sprejetih 26,6 odstotka žensk, od teh jih je umrlo 2,6 odstotka (Takač, 2007, 36). Število je iz leta v leto naraščalo, tako da je celotno število splavov znašalo od 150 do 600, približno 32,5 \% nosečnosti pa se je končalo s splavom (ibid.). N. Budna Kodrič (2003) navaja, da naj bi bilo v Jugoslaviji v tridesetih letih dvajsetega stoletja opravljenih okoli sto tisoč splavov letno (verjetno še več), večinoma zaradi slabega gospodarskega položaja.

Med nalogami, ki so si jih zadala številna ženska društva tega obdobja, je bila razrešitev vprašanja legalizacije splava. Angela Vode je leta 1933 na sestanku Ženskega pokreta podala pobudo za organizacijo zborovanja za legalizacijo splava iz socialnih vzrokov. Ženske organizacije so se zavzemale za spremembo 171. člena kazenskega zakonika. Svojo zahtevo so utemeljevale $\mathrm{v}$ prvi vrsti s socialnimi razmerami, pa tudi z zahtevo po enakopravno- 
sti, saj omenjeni paragraf zadeva samo ženske iz najrevnejših slojev prebivalstva. V svojem proglasu pravijo: „Često vidimo cvetoče in zdrave gospe, $k i$ imajo dovolj sredstev, da bi lahko preživljale kopico otrok, pa so vendar rodile samo enega ali dva. Ne spotikamo se nad tem, saj je njihova osebna pravica, da rode otroke po lastni uvidevnosti. Toda kričeča krivica je v tem, da si te žene lahko kupijo to svobodo in pravico s svojim bogastvom, dočim roma revna žena za isto dejanje v zapor. A kdaj je bila radi tega v zaporu kaka bogata gospa? Zahtevamo enako pravico za vse! (Vode, 1998, 203-204) Pri iskanju podpore drugih ženskih društev so bile neuspešne, saj se jim razen Zveze delavskih žen in Zveze akademsko izobraženih žensk nobeno ni želelo pridružiti. ${ }^{1}$ Do te zahteve so se katoliške ženske organizacije povsem distancirale, liberalne pa so jo podprle le delno (Budna Kodrič, 2003, 41).

Komunistična partija Slovenije je začela o svobodnem odločanju o rojstvu otrok razmišljati med veliko delavsko akcijo v tridesetih letih, »/.../ ker so takrat ženske množično splavljale pri mazačih in ni bilo dovoljeno imeti zdravniške pomoči, razen za velike denarje, splav pa je bil poglavitni socialni problem žensk« (Tomšič, v Geč-Korošec, 1984, 14). V Dubravi je oktobra 1940 potekala 5. državna konferenca Komunistične partije Jugoslavije, ki se je je z referatom udeležila tudi Vida Tomšič. V referatu je izpostavila žensko vprašanje kot del vprašanja proletarske revolucije ter kot »/.../ tisto vzmet, $s$ katero lahko množico žensk vseh slojev strnemo okoli revolucionarnega proletariata in uspešno izkoristimo njihove moči za pomoč proletarski revoluciji « (Tomšič, 1978, 27-28). To so predvsem zahteve, ki zadevajo materinstvo, pri katerem je še posebej izpostavila »/.../ dovoljen splav vse dotlej, dokler ni pogojev, da bi mati rodila otroka brez kakršnih koli skrbi in strahu« (ibid., 28).

Isto pravno stanje se je v političnem prostoru obdržalo tudi po drugi svetovni vojni. Stroka se ni mogla opredeliti za široko legalizacijo socialnih indikacij in legalizacijo tega družbenega pojava, temveč se je togo oklepala zakonskih predpisov, ki so splav dovoljevali le iz medicinskih indikacij.

1 Izkazalo se je, da mnenja niso bila usklajena. Med pomembnejšimi, ki se nista strinjali z legalizacijo abortusa, sta bili predsednica Splošnega ženskega društva Franja Tavčar in zdravnica Ana Zalokar, predsednica ljubljanske sekcije Združenja univerzitetno izobraženih žena Jugoslavije. Prva je izrazila pomisleke zaradi zlorabe odpravljanja nosečnosti, druga pa je bila mnenja, da je naš narod maloštevilen. 


\section{Prvi koraki v smeri liberalizacije odnosa do umetne prekinitve nosečnosti}

Jugoslovansko partijsko vodstvo po koncu druge svetovne vojne ni hitelo $\mathrm{z}$ urejanjem vprašanja umetne prekinitve nosečnosti. "Obstajalo je mnenje, da je o resnični pravici odločanja o rojstvu otrok mogoče govoriti samo pred zanositvijo in da je cilj družbene akcije ustvariti pogoje za to. Odnos do legalizacije splava je bil $v$ začetku restriktiven, četudi je bil sprejet kot ena izmed metod pri načrtovanju družine. Obstajalo je prepričanje, da bi popolna legalizacija splava pri nerazviti zdravstveni službi in bolj ali manj nizki higienski kulturi še bolj ogrozila zdravje ženske in zmanjšala zanimanje za prevencijo.«(Tomšič, v Geč-Korošec, 1981, 10) Problem, do katerega se je bilo treba najprej opredeliti in je zahteval rešitev, je bilo vprašanje in omejitev ilegalnega splava, ki je bil zaradi takratne prepovedi pred drugo svetovno vojno zelo razširjen. Po vojni se je število ilegalnih splavov zunaj zdravstvenih ustanov ob relativno visoki umrljivosti žensk še povečevalo, saj so bili pogosto opravljeni nestrokovno in v neprimernih higienskih razmerah (ibid., 11).

Na predlog poslanca dr. Pavla Lunačka je leta 1951 glede kaznovanja ilegalnega splava prišlo do pomembnega preobrata. Zvezna skupščina FLRJ je izglasovala nov kazenski zakonik, ${ }^{2}$ ki v svojem 140. členu določa, da se kaznuje le izvršilec dejanja; ženske, ki je naredila ilegalni splav ali je dopustila, da se ji ga naredi, pa se ne kaznuje. Sprejem 140. člena kazenskega zakonika pa ni potekal povsem brez zapletov in pomislekov - predvsem o tem, ali je treba kaznovati tudi žensko, ki se je odločila za ilegalni splav. Predlog poslanca Lunačka je brez zadržkov iz povsem praktičnih razlogov podprla medicinska stroka. Menili so, da bodo ženske v primeru zapletov, ki bi nastopili zaradi ilegalnega splava, prej poiskale zdravniško pomoč, kot bi jo, če bi jim zaradi tega grozila kazen. Enega ključnih argumentov, ki je na stališče do zakonika odločilno vplivalo, je podal dr. Potrč, ko je izpostavil družbeno stran vprašanja. Po njegovem mnenju je preganjanje žensk, ki so se odločile za ilegalni splav, neizpodbiten dokaz tiste dvojne morale žensk, ki se pripisuje meščanskim družbam. »Vemo, da pred sodišče pride

2 Uradni list FLRJ, št. 13, 1951. 
zelo majhen odstotek žensk, in to ne tistih, ki bi morale, tistih, ki splavijo iz luksuza, temveč tiste, ki so žrtve naključja; takšno kaznovanje bi bilo torej zgolj simbolično. Mislim, da bi ta simbolika pomenila prav tisto, proti čemur se je bojevalo napredno delavsko gibanje, namreč proti ostankom neenakopravnosti med moškim in žensko /.../ Mislim, da bomo prav gotovo naredili zgodovinski napredek, če se odrečemo kaznovanju ženske. S tem se ne odrekamo boju za splav, pač pa se zanašamo na druga sredstva, ki so boljša in učinkovitejša." (Potrč, v Tomšič, 1976, 314)

Na podlagi 140. člena kazenskega zakonika in na pobudo Sveta za ljudsko zdravstvo in socialno politiko je bila 11. januarja 1952 izdana Uredba o postopku za dovoljeno odpravo plod $u^{3}$ (v nadaljevanju Uredba). Uredba je pomenila prvo sprostitev zakonskih določil glede dovoljenega splava in je tako olajšala pravni položaj nosečnic, ki so se odločile za splav. Zvezni predpis je legaliziral splav iz medicinskih, pravnih, zdravstveno-socialnih in $s$ tem povezanih socialnih indikacij. Medicinske indikacije so določale, da se splav dovoli, če bi nosečnost ogrozila življenje ženske ali hudo prizadela njeno zdravje ter če je na podlagi medicinske znanosti utemeljeno pričakovati, da se bo otrok zaradi bolezni staršev rodil s hudimi telesnimi ali duševnimi hibami; če je bila nosečnost posledica kaznivega dejanja (posilstva, spolnega občevanja s slabotno osebo, spolnega občevanja z mladoletno osebo, spolnega občevanja z zlorabo položaja, zapeljevanja ali krvoskrunstva). Uredba predvideva možnost, da je mogoče upoštevati socialne razloge, če bi zaradi posebno hudih materialnih, osebnostnih ali družinskih razmer otrokovo rojstvo ogrozilo materino zdravje. Prekinitev nosečnosti je dovoljena praviloma samo v prvih treh mesecih v bolnišnici ali na ginekološki kliniki. Pri ginekoloških zavodih so bile ustanovljene zdravniške dvostopenjske komisije, ${ }^{4}$ ki so presojale o zahtevi za odpravo plodu.

Formulacija, podana v Uredbi, je komisijam omogočala prožnejšo prakso, hkrati pa ni odpirala vrat za legalizacijo splava. Treba je pojasniti, da

3 Uredba o postopku za dovoljeno odpravo plodu. Ur. l. FLRJ, št. 4/1952 (19.1.1952).

4 Če je komisija prve stopnje zavrnila zahtevo po umetni prekinitvi nosečnosti, je noseča ženska lahko zahtevala, da o zadevi odloči zdravniška komisija druge stopnje. Odločba zdravniške komisije druge stopnje je bila dokončna. Obe komisiji so sestavljali trije zdravniki oz. zdravnice, od katerih je moral biti eden specialist oz. specialistka za ginekologijo. 
vladajoča oblast $\mathrm{v}$ tem obdobju ni bila nikoli naklonjena popolni legalizaciji splava in uporabi splava kot obliki kontracepcije, kar lahko zasledimo v številnih evropskih socialističnih državah tistega časa. Vida Tomšič (1954, 13) je v Borbi zapisala: "Določili smo samo splošno usmeritev, da naša družba splav zavrača, vendar pa besedilo zakonika in uredbe o postopku za dovoljevanje splava vendarle omogoča, da se pravne norme prožno uporabljajo." Po njenem mnenju je legalizacija splava sicer na prvi pogled videti zelo preprosta, vendar pa bi zapletla razmere v medicini pri nas.

Uredba je kljub vsemu za številne ženske pomenila zapleten in ponižujoč postopek uveljavljanja možnosti umetne prekinitve nosečnosti pred posebno komisijo. Kot je nazorno ponazoril dr. Cerar, je bila »komisija križ božji za vsako žensko /.../ Brati tiste prošnje je bila prava groza. (Zajc, v Bahovec, 1991, 35) Zato se je kot druga možnost še naprej obdržal ilegalni splav, ki je v petdesetih letih naraščal. Leta 1955 je bilo zabeleženih 5451, leta 1958 10641 in leta 196114856 splavov; od tega je bilo komisijsko dovoljenih splavov leta 1955 441, 19584670 in 9291 splavov leta 1961 (Tomšič, 1971).

Takšno stanje je privedlo do tega, da so leta 1953 ginekologi in ginekologinje na oktobrskem Kongresu ginekologov in porodničarjev Jugoslavije sprejeli resolucijo, ki je zahtevala, da se splav kot družbeno škodljiv pojav prepove. Zgolj socialnih razlogov po njihovem mnenju ni mogoče priznati kot zadostnih za umetno prekinitev nosečnosti, priznava se samo socialna komponenta, povezana $\mathrm{z}$ zdravstvenimi razlogi. Resolucija nadalje pojasnjuje, da ni smiselno kaznovati samo osebe, ki splav opravi, ampak tudi žensko, ki sama opravi splav ali drugemu dopusti, da ga opravi. Iz tega posledično sledi poziv k spremembi kazenskega zakonika. Kongres je širjenje kontracepcijske miselnosti označil kot depopulacijski ukrep, kontracepcijske metode in sredstva pa ocenil kot neučinkovita. Resolucija je naletela na velik odpor v širši javnosti, prepričala pa ni niti vseh zdravnikov in zdravnic. ${ }^{5}$ Pri problemu, ki ni samo medicinski, temveč predvsem družbeni, se je medicinska stroka odločila za staro obliko boja s sredstvi pregona, kljub

5 Zdravniška stroka tedaj ni bila enotna, saj so nekateri njeni predstavniki kasneje v javnosti dajali predloge, ki so bili popolnoma v nasprotju s sklepi kongresa. Dr. Gikić je bil na primer mnenja, da je že to, da je dekle neporočeno, zadosten razlog za legalni splav (Tomšič, 1987, $318)$. 
dejstvu, da tu niti najstrožji zakoni ne pomagajo. Proti resoluciji je zelo kritično nastopila Vida Tomšič $(1987,317)$, češ da »/.../ ginekologi niso opazili, da se s svojimi stališči uvrščajo med tiste, ki že od nekdaj menijo, da je ženska vir in krivec vsega zla«. Spraševala se je tudi, kako morejo ginekologi misliti, da bo strah pred kaznijo ženske odvrnil od splava, če jih od njega ne more odvrniti niti spoznanje, da jih lahko splav stane življenje (ibid.). Prepoved števila splavov ne zmanjša kaj dosti, saj je njen poglavitni učinek nekontrolirano naraščanje ilegalnih splavov z velikim zdravstvenim tveganjem.

Kljub kongresnemu sklepu ni prišlo do nobenih zakonskih sprememb. Država se je odločila za postopno liberalizacijo splava, ki naj bi preprečila vsaj nestrokovno opravljene ilegalne splave, ter za pospešeno uporabo in popularizacijo kontracepcije.

\section{Preventiva dobi prednost pred splavom}

Širše družbeno sprejetje moderne kontracepcije zahteva predvsem njeno razpoložljivost, dostopnost ter splošno sprejetje, da je dosledna uporaba kontracepcije bolj priporočljiva kot zanašanje na splav. V nekdanjih socialističnih državah, še posebej v Sovjetski zvezi in Romuniji, politika kontracepcije ni bila dojeta kot normativna razlika med kontracepcijo kot odgovorno in legitimno in splavom kot (nujnim) zlom. Politika splava na zahtevo se je v teh državah uveljavila pred izumom in masovno produkcijo modernih kontracepcijskih sredstev in tako je splav postal primarna metoda uravnavanja rojstev (Stloukal, 1999, 25). Moderne kontracepcijske metode, še posebej tiste, namenjene ženskam, so bile dojete kot nekaj nenaravnega, nezadostnega in nasploh nevarnega. Moderna sredstva kontracepcije so bila $\mathrm{v}$ tistem času praktično nedostopna, sama oblast pa tudi ni nudila nobenih informacij o njih ali spodbujala njihove uporabe.

V SFRJ se je tedanja oblast $z$ Vido Tomšič na čelu še posebej zavzeto bojevala za širjenje sodobnih kontracepcijskih metod. Po njenem mnenju (1978) kontracepcija ne velja samo za uspešno orodje boja proti splavu, ampak je združljiva tudi z današnjim pogledom na položaj žensk, lahko pa postane tudi pomemben dejavnik za krepitev družine. Država si je priza- 
devala, da postane obveščanje in izobraževanje za odgovornost $\mathrm{v}$ spolnem odnosu integralni del priprave otrok in mladine na življenje. Kot prvi pogoj za uresničevanje pravice do svobodnega in zavestnega starševstva je videla v obstoju sredstev in storitev, ki slehernemu posamezniku omogočajo, da spolni odnos loči od prokreacije in da so ta sredstva tudi dostopna (1976).

Istočasno s pobudami za legalizacijo splava so ginekologi in ginekologinje pričeli v slovenski prostor uvajati kontracepcijo. Kljub kongresnemu sklepu leta 1953 je dr. Franc Novak med letoma 1953 in 1954 Svetu za zdravstvo in socialno politiko Slovenije predstavil potrebo po domači proizvodnji kontracepcijskih sredstev in program razvoja kontracepcijske službe v Sloveniji. Kot je dejal sam (Naša žena, 1973, 23), se je zavedal, da zdravnik ne more preprosto reči, da je splav škodljiv, zato naj bo prepovedan. Vse, kar taka prepoved po njegovem mnenju doseže, je, da pošlje žensko naravnost $\mathrm{k}$ mazaču, ki bo svoje delo opravil tudi na hudo nečeden način grobo, nevarno in ponavadi brezvestno. Zavedal se je, da je treba splav v določenih okoliščinah dovoliti, vendar ga je brez sočasnega širjenja kontracepcijskih sredstev nemogoče zajeziti. Bil je prvi, ki je informacije o kontracepciji predstavil slovenskim ženskam, in sicer leta 1954, ko je za revijo Naša žena objavil členek $\mathrm{v}$ treh delih $\mathrm{z}$ naslovom "Spočetje po naši volji ali o kontracepciji«. V okviru omenjene revije sta izšli tudi dve brošuri, „Spočetje po naši volji (1955) in "Materinstvo naj bo zavestno" (1964). Pod obe se je podpisal Franc Novak. Leta 1955 je na njegovo pobudo tovarna Sava iz Kranja izdelala prvo diafragmo, tovarna Lek pa prvo kontracepcijsko pasto. To letnico lahko pri nas upravičeno štejemo za začetek organizirane kontracepcijske službe v Sloveniji (Hren Božič, v Takač, 2007, 39). Tisti čas smo bili ena redkih držav z lastno produkcijo kontracepcijskih sredstev.

Zaradi potrebe, da bi ženske zavarovali pred posledicami nedovoljene in nezaželene nosečnosti, je bila 1. decembra 1955 ustanovljena prva samostojna ordinacija za kontracepcijo v Jugoslaviji, ki je delovala v okviru Centralnega ginekološkega dispanzerja v Ljubljani. Leta 1957 je bila na ginekološki kliniki v Ljubljani ter na oddelku za ginekologijo in porodništvo v Mariboru ustanovljena kontracepcijska ambulanta.

Velikega pomena je bilo posvetovanje zdravstvenih in družbenih delavcev in delavk v Beogradu med 7. in 9. majem 1958. Najpomembnejši 
sklepi so bili, da kontracepcijska služba postane preventivni ukrep zdravstvene službe proti splavu kot zdravstvenemu in družbenemu zlu; postopek v primerih dovoljenega splava se humanizira; prične se s koordiniranim poučevanjem spolne vzgoje in reševanjem te problematike na osnovi družbene morale - enakopravnih odnosov med spoloma; kontracepcijska služba postane integralni del zdravstvene službe. ${ }^{6}$ Istega leta je nastopila velika razširitev kontracepcije po vsej Sloveniji, saj je bilo do konca leta ustanovljenih 41 kontracepcijskih posvetovalnic. V SR Sloveniji je bilo leta 196981 dispanzerjev za ženske in 74 posvetovalnic, enajst let kasneje pa 74 dispanzerjev in 41 posvetovalnic (Krajnc-Simoneti, 1981, 11).

Leta 1963 je bila v Sloveniji izvedena študija, ki je v svoj vzorec zajela 1960 žensk. Rezultati so pokazali, da je bila v 44 odstotkih najpogostejša kontracepcijska metoda coitus interruptus, 22 odstotkov jih je uporabljalo diafragmo, 5 odstotkov kondome, 10 odstotkov pa je imelo izkušnje z večjim številom metod. Študija je pokazala, da 19 odstotkov žensk ni uporabljalo nobene kontracepcije. Po mnenju 30 odstotkov žensk je bil splav sprejemljiva metoda regulacije nosečnosti (Andoljšek, v David, 1999, 303). Po podatkih Zdravstvenega statističnega letopisa (2002) je leta 1969 v Sloveniji hormonsko kontracepcijo uporabljalo 5,4 odstotka žensk v rodni dobi, intrauterino pa trije odstotki žensk. Delež uporabnic teh dveh najzanesljivejših metod se je z leti spreminjal: 14 odstotkov in 7 odstotkov leta 1976, 10 odstotkov in 20 odstotkov leta 1989 ter 18 odstotkov in 7 odstotkov leta 2002.

V letu 1960 je bila sprejeta Uredba o pogojih in postopku za dovolitev splava ${ }^{7}$ in Navodilo za izvrševanje Uredbe o pogojih in postopku za dovolitev splava. ${ }^{8}$ Nov predpis je natančneje opredelil socialne indikacije. Ob določenih medicinskih, pravnih in socialnih pogojih je uredba splav dovoljevala. Končno je bil istega leta v Sloveniji splav dovoljen na podlagi socialnih indikacij. O odobritvi splava so tudi po novi uredbi odločale komisije prve in druge stopnje. Pomembno je poudariti, da so prav te komisije odigrale po-

6 AS 1413, Vida Tomšič, škatla 197. Informacija o kontracepcijski službi v Ljudski republiki Sloveniji. Ljubljana, 28. 9. 1960.

7 Uredba o pogojih in postopku za dovolitev splava. Ur. l. FLRJ, št. 9/1960.

8 Navodilo za izvrševanje Uredbe o pogojih in postopku za dovolitev splava. Ur. l. FLRJ, št. 52/1960. 
membno vlogo pri preprečevanju izzvanega ilegalnega splava, saj so prosilkam ugodile v 98 odstotkih (Takač, 2007, 41). Dovoljen splav je poleg tega zmanjšal smrtnost žensk zaradi ilegalnih splavov. Maternalna smrtnost v Sloveniji, katere vzrok je bil splav, se je od leta 1961 zmanjševala. Tako je bilo leta 1961 zabeleženih 10 smrtnih primerov zaradi splava, leta 1965 šest, leta 1970 in 1979 pa štirje oziroma eden (Krajnc-Simoneti, 1981, 41).

Ob spoznanju, da število splavov iz leta v leto narašča (do neke mere je sicer prišlo do omejitve splava zunaj zdravstvenih ustanov) in da po tej poti ne bo mogoče ustrezno reševati vse večjih zahtev po splavu, se je pričelo težiti h kompleksnejši akciji, katere težišče je bilo na preprečevanju splava, širjenju kontracepcije in povečani odgovornosti starševstva.

\section{Načrtovanje družine kot nove politike v Sloveniji}

Z ustanovitvijo koordinacijskega odbora za načrtovanje družine leta 1961 v Ljubljani se je prav v Sloveniji pričel proces načrtovanja družine. Leta 1963 je bil na zvezni ravni oblikovan Koordinacijski odbor, ki naj bi se ukvarjal z vprašanjem družine. Leta 1967 se je preoblikoval v Zvezni svet za načrtovanje družine. Istega leta je Jugoslavija vstopila v Mednarodno organizacijo za načrtovano starševstvo (International Planned Parenthood Federation - IPPF).

Svet za zdravstvo SR Slovenije je aprila 1961 ustanovil Znanstveno-raziskovalni oddelek za vprašanje splava in kontracepcije kot posebno enoto Klinične bolnišnice za porodništvo in ginekologijo, ki jo je vodila dr. Lidija Andoljšek Jeras. Istega leta je bil v Sloveniji ustanovljen tudi Koordinacijski odbor za načrtovanje družine, ki se je leta 1963 preimenoval v Oddelek za prevencijo splava, leta 1967 pa v Inštitut za načrtovanje družine (IND). IND se je pod vodstvom dr. Lidije Andoljšek Jeras razvil v institucijo, katere temeljni cilj je bil varovanje reproduktivnega zdravja žensk v Sloveniji (Meden-Vrtovec, v Takač, 2007, 44). Inštitut je raziskoval medicinske in z njimi povezane družbene vidike načrtovanja družine, preučeval vprašanja rodnosti in neplodnosti, pa tudi sociološka, medicinska in psihološka vprašanja splava in njegovo preprečevanje. 
V Sloveniji so se v šestdesetih letih dvajsetega stoletja pričeli uveljavljati programi za načrtovanje družine. Temeljili so na informiranju in izobraževanju otrok, mladine in odraslih o načelih načrtovanega rojevanja, uporabi sodobnih kontracepcijskih metod za uspešno uresničevanje teh metod in o načinih odkrivanja in zdravljenja neplodnosti. To delo je prevzelo predvsem zdravstveno osebje v dispanzerjih za ženske. Stanka Kranjc-Simoneti (1999, 29-30) navaja, da je bilo leta 1960 v Sloveniji okoli 70 dispanzerjev za ženske, v njih pa je delalo približno 60 zdravnikov oz. zdravnic, večinoma ginekologov oz. ginekologinj.

Do leta 1969 so bile zaradi zmanjšanja ilegalnega splava (pa tudi legalni splav je začel po velikem porastu leta $1962 \mathrm{v}$ nekaterih republikah polagoma stagnirati) ustvarjene razmere za kompleksnejše obravnavanje načrtovanja družine.

Pomemben mejnik v zakonodaji v zvezi z umetno prekinitvijo nosečnosti pomeni Resolucija o planiranju družine. ${ }^{9}$ Ta temeljni dokument je zvezna skupščina sprejela 25. aprila 1969. Dokument dolgoročno opredeljuje politiko načrtovanja družine, izhaja pa iz načela svobodnega odločanja o številu rojstev (ki vključuje tudi odločitev o umetni prekinitvi nosečnosti) in presledkov med njimi kot človekovi pravici ter iz težnje, da je novorojeni otrok zaželen. Resolucija se je zavzemala za preprečevanje nezaželenega spočetja $\mathrm{z}$ uporabo kontracepcije, umetno prekinitev nosečnosti pa ocenila kot najmanj primeren način uravnavanja rojstev. Kot dolžnost celotne družbe, ki jo ima do staršev, resolucija navaja zagotavljanje pogojev za pridobivanje znanja in sredstev, s katerimi bodo lahko starši uresničevali pravico do načrtovanja družine. Resolucija prav tako predvideva aktivnejšo vlogo posameznih služb, znanstvenih institucij in družbenih organizacij pri vzgojno-izobraževalnih dejavnostih ter dejavnostih na področju zdravstva in socialnega varstva (ki naj bodo usmerjene k širjenju znanja in možnosti za uporabo kontracepcije).

Vse to je pripomoglo k temu, da je bila v novo zvezno ustavo leta 1974 kot človekova pravica zapisana tudi pravica o svobodnem odločanju o rojstvu otrok.

9 Resolucija o planiranju družine. Ur. l. SFRJ, št. 20/1969, leto XXV (8.5.1969). 
Istočasno z Resolucijo o načrtovanju družine je jugoslovanska zvezna skupščina sprejela tudi Splošni zakon o prekinitvi nosečnosti, ${ }^{10}$ ki ureja splošne pogoje, pod katerimi se lahko izvrši poseg umetne prekinitve nosečnosti. Na podlagi tega zakona so posamezne republike sprejele svoje zakone. Po 9. členu tega zakona so se še naprej uporabljala določila iz Uredbe o pogojih in postopku za dovolitev splava iz leta 1960 in iz navodil za izvrševanje Uredbe o pogojih in postopku za dovolitev splava iz istega leta, če njune določbe niso nasprotovale določilom splošnega zakona. Za dovolitev predčasne prekinitve nosečnosti so morale biti podane zdravstvene, evgenične ali socialne indikacije. Zdravstvene indikacije določa 1 . točka 3. člena Splošnega zakona o prekinitvi nosečnosti. Prekinitev nosečnosti je dovoljena s privolitvijo oziroma na zahtevo noseče ženske takrat, ko se po medicinskih indikacijah ugotovi, da ni mogoče na drug način rešiti življenja ali odvrniti hude okvare njenega zdravja med nosečnostjo, porodom ali po porodu. Evgenične indikacije so bile določene v 2. točki 3. člena; splav je bil dovoljen, ko je bilo po znanstvenih spoznanjih mogoče pričakovati, da se bo otrok zaradi bolezni staršev rodil s hudimi telesnimi ali duševnimi hibami. Kazenske indikacije so bile naštete v 3. točki 3. člena, kadar je prišlo do spočetja v zvezi s kaznivim dejanjem posilstva, spolnega občevanja s slabotno osebo, spolnega občevanja $z$ mladoletno osebo, spolnega občevanja z zlorabo položaja, zapeljevanja ali krvoskrunstva. Socialne indikacije je določal 4. člen, po katerem je bila na zahtevo noseče ženske prekinitev nosečnosti dovoljena, če bi utegnila ženska med nosečnostjo ali po porodu priti v hude osebne, družinske, materialne ali druge razmere.

\section{Svobodno odločanje o rojstvu otrok kot ustavna pravica}

Ustava SFRJ, ki je bila sprejeta 21. februarja 1974, je v 191. členu določala, da je "pravica človeka, da svobodno odloča o rojstvu svojih otrok. Ta pravica se lahko omeji samo iz zdravstvenih razlogov. "Jugoslavija je tako postala prva država na svetu, ki je v ustavo zapisala pravico posameznika

10 Splošni zakon o prekinitvi nosečnosti. Ur. l. SFRJ, št. 20/1969, leto XXV (8.8.1969). 
oz. posameznice, da se svobodno odloča o rojstvu otrok (David, 1999, 281). Ustave $\mathrm{v}$ republikah in pokrajinah so glede umetne prekinitve nosečnosti prinašale enake predpise. Ustava SR Slovenije ${ }^{11}$ je imela za razliko od drugih republiških in pokrajinskih ustav v 233. členu še dodatek; njen člen se glasi: "Pravica človeka je, da svobodno odloča o rojstvu otrok. Ta pravica se lahko omeji samo iz zdravstvenih razlogov. V zvezi z uresničevanjem te pravice zagotavlja družbena skupnost potrebno izobrazbo ter ustrezno socialno varstvo in zdravstveno pomoč $v$ skladu z zakonom. «233. člen torej državo zavezuje, da zagotavlja dostop do ustreznega zdravstvenega varstva med nosečnostjo in porodom, pravico do izbire števila otrok in razmikov med njimi ter reproduktivno zdravstveno varstvo in informacije na tem področju.

Sprejetje 191. člena ustave pa je prineslo kar nekaj nerazumevanja, kaj pravzaprav spada pod »načrtovanje družine«. Javna razprava je bila dolga in naporna. V njej so se izpostavila naslednja vprašanja: ali gre za individualno pravico predvsem ženske ali za pravico zakoncev; kaj je svoboda in kaj odgovornost in dolžnost kot ustavna formulacija; kaj naj bo ustavna vsebina otrokove pravice, da se rodi zaželen; v čem je odgovornost družbe itd. (Tomšič, 1976, 376). Razprava je pokazala, da se je načrtovanje družine vse prepogosto enačilo s populacijsko politiko - in to vselej z namenom, da bi zmanjšali nataliteto, kar naj bi dosegli s propagiranjem sredstev za preprečevanje nezaželene nosečnosti (kontracepcija, sterilizacija, splav). V. Tomšič $(1980,114)$ se nikakor ni strinjala s tistimi, ki so v okviru širjenja planiranja družine poskušali najti ali so propagirali tako imenovano »idealno« število otrok na družino oziroma »idealni obseg družine«. Pravi (ibid.), da je ideal družbe odgovorna odločitev staršev, da imajo veliko otrok ali da nimajo niti enega, idealni so humani odnosi med spoloma in odnos spolne odgovornosti do otroka in ne število otrok. Pri tem je poudarjala, da se je socialistično delavsko gibanje že zdavnaj bojevalo za možnost svobodnega odločanja o rojstvu otrok in $\mathrm{v}$ tem okviru za dostopnost do legalnega splava in kontracepcije kot sestavnega dela svojega boja za enakopravnost ženske in žensko osamosvojitev (ibid., 110). Zagovorniki načrtovanja družine so poudarjali, da načrtovanje družine ni samo kontracepcija in tudi ne samo splav ter da populacijsko politiko sestavlja veliko več prvin, ne zgolj vpliva-

11 Ustava Socialistične republike Slovenije. Ur. 1. SRS, št. 6/1974 (25.2.1974). 
nje na dostopnost sredstev za načrtovanje družine. V. Tomšič $(1976,350)$ je poudarjala, da pravica do svobodnega starševstva ni bila nikoli enačena s pravico do izzvanega splava. Takšen medicinski poseg, nadaljuje, ni ugoden za zdrav in naraven potek nosečnosti, vendar ga je, ne glede na zakonski stan in materialno stanje, treba narediti dopustnega vsem ženskam $\mathrm{v}$ tistih primerih, ko bi bilo rojstvo otroka iz raznih, tudi nemedicinskih razlogov nezaželeno. V tem okviru je bil splav v SFRJ legalizirano sredstvo za načrtovanje družine in dostopno po določenem postopku in $\mathrm{v}$ določenem času - deset tednov po zanositvi.

Ustavno določilo o svobodnem odločanju o rojstvih po mnenju nekaterih velja za eno najmodernejših ustavnih določil na tem področju v svetu, ki prav tako ne prihaja $\mathrm{v}$ kolizijo $\mathrm{z}$ demografskimi gibanji in stremljenji $\mathrm{v}$ takratni Jugoslaviji (Andoljšek, Kožuh-Novak in Obersnel-Kveder, 1991, 193).

Ustavna opredelitev pravice do svobodnega odločanja o rojstvu otrok je spodbudila sprejetje še drugih predpisov na socialnem in vzgojno-izobraževalnem področju $\mathrm{v}$ republikah. Zvezna ustava je nekatere zadeve definirala dokaj široko in na ta način republikam omogočila, da to področje glede na svoje specifične značilnosti natančneje uredijo $v$ republiških ustavah in zakonih.

\section{Sprejem liberalne zakonodaje v Sloveniii v sedemdesetih letih}

V Sloveniji sta bila v sedemdesetih letih dvajsetega stoletja sprejeta dva bistvena dokumenta, ki uravnavata eno najbolj občutljivih in intimnih področij v človekovem življenju. Skupščina RS je leta 1974 sprejela Resolucijo o načrtovanju družine in družbenih prizadevanjih za njen nastanek in varnost, ${ }^{12}$ leta 1977 pa je bil razglašen Zakon o zdravstvenih ukrepih pri uresničevanju pravice do svobodnega odločanja o rojstvu otrok. ${ }^{13}$

12 Resolucija o načrtovanju družine in družbenih prizadevanjih za njen nastanek in varnost. Ur. l. SRS, št. 18/1974, leto XXX (10.5.1974).

13 Zakon o zdravstvenih ukrepih pri uresničevanju pravice do svobodnega odločanja o rojstvu otrok. Ur. l. SRS, št. 11/1977 (19.5.1977). 
Resolucija o načrtovanju družine je pomenila logično nadgradnjo zvezne Resolucije o načrtovanju družine. Resolucija vse družbene dejavnike zavezuje h koordinirani akciji, ki temelji na uresničevanju razmer za nastanek in varnost družine, uveljavljanju socialističnih družbenomoralnih načel v odnosih med spoloma, polni medsebojni odgovornosti do rojstva, vzreje in vzgoje otrok pri vstopanju v spolne in zakonske odnose ter omogočanju svobodne odločitve glede uravnavanja časa spočetja in rojstev kot izraza odgovornosti do otroka, da se rodi zaželen in da starši odgovorno sprejemajo njegovo rojstvo (Resolucija o ..., 1977). Poleg tega različne družbeno-politične organizacije, društva in skupnosti zavezuje, da s svojim delovanjem načrtno ustvarjajo ugodne razmere za rojstvo in razvoj otrok. To uresničujejo $\mathrm{z}$ ustrezno stanovanjsko, zdravstveno in vzgojno-izobraževalno politiko, s potrebnim poudarkom na družbenih oblikah varstva in vzgoje otrok ter varstva matere, s politiko zaposlovanja in nenehnim izboljševanjem delovnih razmer ter s prostorskim in družbeno-ekonomskim načrtovanjem.

Zakon o zdravstvenih ukrepih pri uresničevanju pravice do svobodnega odločanja o rojstvu otrok je stopil v veljavo 26. aprila 1977. Pomenil je izpolnitev ustavne pravice do svobodnega odločanja o rojstvu otrok. $\mathrm{V}$ njem so predstavljeni naslednji zdravstveni ukrepi, s katerimi se uravnava rojstvo otrok: preprečevanje zanositve, umetna prekinitev nosečnosti ter ugotavljanje in zdravljenje zmanjšane plodnosti.

Zakon je določil, da je preprečevanje zanositve lahko začasno, če se redno uporabljajo kontracepcijska sredstva, in stalno, če se izvrši sterilizacija. Glede kontracepcije zakon v 7. členu določa samo, da imata ženska in moški pravico, da jima zdravnik svetuje ali predpiše zanju najprimernejše sredstvo za začasno preprečevanje zanositve. V 10. členu zakon navaja, da se sme sterilizacija izvesti le po 35 . letu starosti ženske.

Umetno prekinitev nosečnosti obravnavajo členi od 17 do 30. Člen 17 pravi, da je umetna prekinitev nosečnosti medicinski poseg, ki se opravi na zahtevo nosečnice, če njena nosečnost ne traja več kot deset tednov. Umetna prekinitev nosečnosti, ki traja več kot deset tednov, se lahko na zahtevo nosečnice opravi le, če je nevarnost posega za življenje in zdravje nosečnice ter za njena prihodnja materinstva manjša od nevarnosti, ki grozi nosečnici 
ali otroku zaradi nadaljevanja nosečnosti in zaradi poroda (18. člen). Postopek za prekinitev nosečnosti se prične na zahtevo ženske. Za nosečnico, ki je nerazsodna, zahtevajo umetno prekinitev nosečnosti njeni starši oziroma skrbniki. Kadar nosečnost ne traja več kot deset tednov, je postopek prekinitve nosečnosti po zakonu zelo preprost. Nosečnica vloži zahtevo za umetno prekinitev nosečnosti skupaj z izvidom o trajanju nosečnosti in drugimi medicinskimi izvidi zdravstveni organizaciji, ki opravlja postopek umetne prekinitve nosečnosti. Če je iz izvidov nosečnice razvidno, da so podani zdravstveni razlogi zoper umetno prekinitev nosečnosti, se nosečnico napoti h komisiji prve stopnje. Poudariti je treba, da komisija ne odloča o prekinitvi nosečnosti, ampak nosečnici predloži razloge, ki so podani zoper njeno odločitev, in opozori na posledice, ki bi jih umetna prekinitev nosečnosti utegnila povzročiti. Zahtevo nosečnice, pri kateri nosečnost traja več kot deset tednov, obravnava komisija prve stopnje. Če je odločitev komisije negativna, se lahko nosečnica pritoži na komisijo druge stopnje, ki o tem odloči v sedmih dneh. S. Simoneti (Simoneti Krajnc in drugi, 1976) navaja, da je bila večina prošenj, ki so jih komisije obravnavale, odobrena. Tako naj bi bilo leta 1972 odobrenih 95 odstotkov vseh prošenj. Skoraj 95 odstotkov odobritev je temeljilo na socialnih, 3-4 odstotki na medicinskih in 1 odstotek na kazenskopravnih indikacijah (ibid.).

Zakon o zdravstvenih ukrepih posebej določa, da zdravstveno osebje ter zdravstvene organizacije in socialni delavci in delavke, ki sodelujejo v postopku, nosečnice seznanijo s postopkom, potekom in posledicami umetne prekinitve nosečnosti ter $\mathrm{z}$ metodami in sredstvi za preprečevanje nosečnosti.

Zakone, ki urejajo prekinitev nosečnosti, so sprejele tudi vse ostale republike in obe avtonomni pokrajini. ${ }^{14}$ Po zakonih posameznih republik in obeh avtonomnih pokrajin je umetna prekinitev nosečnosti medicinski poseg, ki se opravi na zahtevo nosečnice, če njena nosečnost ne traja več kot deset tednov, in pod pogojem, da se s prekinitvijo nosečnosti ne ogroža življenje ali zdravje ženske. Zakon republike Makedonije ob tem še dodaja,

14 V Bosni in Hercegovini, Srbiji in na Kosovu to področje ureja zakon iz leta 1977; leta 1978 je zakon stopil v veljavo na Hrvaškem in v Vojvodini, leta 1979 pa še v preostalih dveh republikah, Makedoniji in Črni Gori. 
da se nosečnost ne more umetno prekiniti, če od prekinitve prejšnje nosečnosti ni preteklo eno leto. Umetna prekinitev nosečnosti, ki traja več kot deset tednov, se opravi na zahtevo nosečnice le, če to posebna komisija odobri, in pod pogoji, ki jih določajo zakoni. Posamezni zakoni pri tem določajo medicinske, evgenične, kazenskopravne ali socialne indikacije. Zakoni Bosne in Hercegovine, Hrvaške in Vojvodine poznajo samo prve tri skupine indikacijskih razlogov za prekinitev nosečnosti; ne poznajo torej socialnih razlogov, tako da se iz teh razlogov prekinitev nosečnosti, ki traja več kot deset tednov, ne more dovoliti. Zakona republike Hrvaške in Makedonije ne omejujeta možnosti prekinitve nosečnosti na nosečnost, ki traja največ dvajset tednov. Zakoni republik in avtonomnih pokrajin se razlikujejo v ureditvah o predlogih za prekinitev nosečnosti mladoletne nosečnice. V Bosni in Hercegovini je tako mogoče, da sme sama vložiti predlog za prekinitev nosečnosti le tista mladoletna nosečnica, ki je že dopolnila 16 let in si sama ustvarja sredstva za življenje. Če ta dva pogoja nista izpolnjena, morajo predlog vložiti starši ali skrbnik. Važno je tudi določilo, da se mladoletni nosečnici, ki je že stara 14 let, ne more umetno prekiniti nosečnosti brez njenega soglasja. Starost 16 let je tudi na Hrvaškem in v Vojvodini pogoj, da sme nosečnica sama podati predlog za prekinitev nosečnosti, v nasprotnem primeru se zahteva soglasje ali privolitev staršev ali skrbnika. Ostale republike in avtonomna pokrajina za prekinitev nosečnosti mladoletni osebi zahtevajo soglasje staršev oziroma skrbnika.

Zakoni niso postavljali pogoja, da mora ženska v primeru, ko želi umetno prekiniti nosečnost, potrebovati privolitev partnerja ali moža. Umetna prekinitev nosečnosti je prepoznana kot individualna pravica posameznice in ne pravica para ali zakoncev. Umetna prekinitev nosečnosti se je opravljala v splošnih, specialnih in kliničnih bolnišnicah ter v zdravstvenih organizacijah, ki jih je za to posebej pooblastil Republiški komite za zdravstveno in socialno varstvo. $\mathrm{V}$ manjših mestih, ki niso imela ustreznih ustanov in osebja, so umetno prekinitev nosečnosti opravljale potujoče medicinske službe (David, 1999). Zaposlena ženska je bila upravičena do plačanega dopusta za čas, ki ga je zaradi umetne prekinitve nosečnosti preživela $\mathrm{v}$ bolnišnici. Umetna prekinitev nosečnosti je bila brezplačna ter krita s strani zdravstvenega zavarovanja (Kapor-Stanulovic, v David, 1999, 307). 


\section{Zaključek}

Liberalizacija umetne prekinitve nosečnosti sredi petdesetih let prejšnjega stoletja pomeni precejšen napredek na področju reproduktivnih pravic ženske.

Od leta 1929 so bile v Jugoslaviji uzakonjene medicinske indikacije za umetno prekinitev nosečnosti, dobrih dvajset let kasneje pa so bile medicinskim, z Uredbo iz leta 1952, dodane še socialno-medicinske. Uredba pomeni prvo sprostitev zakonskih določil glede umetne prekinitve nosečnosti v Jugoslaviji. Od tega leta beležimo tudi uvajanje širših socialnih indikacij za splav, da bi se na ta način zmanjšala potreba po nestrokovnem in nevarnem ilegalnem splavu. Od leta 1960 predpisi vključujejo tudi obvezno svetovanje za preprečevanje nezaželene nosečnosti ter razširjanje dostopnosti sredstev za to. Zvezna resolucija o načrtovanju družine, sprejeta leta 1969, je zavzela stališče, da je svobodno odločanje o rojstvih otrok ena temeljnih človekovih pravic, poudarja pa tudi, da je osnovni način uravnavanja in preprečevanja nezaželene nosečnosti kontracepcija. Z ustavnimi spremembami od leta 1971 do 1974 so postale skoraj vse pristojnosti s področja zdravstva, socialne politike in izobraževanja zadeva republik in pokrajin.

Ustavno načelo iz leta 1974 o pravici do svobodnega odločanja o rojstvu otrok je postalo osnova za sprejetje ustrezne zakonodaje leta 1977 v Sloveniji. Zakon o zdravstvenih ukrepih pri uresničevanju pravice do svobodnega odločanja o rojstvu otrok pomeni eno najbolj liberalnih zakonodaj, ne samo v jugoslovanskem, temveč tudi evropskem in svetovnem prostoru. Sčasoma so se med federalnimi enotami v pravnih podlagah načrtovanja družine pojavile precejšnje razlike. Pravico do načrtovanja družine, ki je bila leta 1974 zapisana v zvezno ustavo, je večina bivših jugoslovanskih republik interpretirala le kot pravico do splava. Slovenski in hrvaški zakon sta bila izjema, saj sta poleg umetne prekinitve nosečnosti urejala tudi druge, $\mathrm{v}$ sodobni medicini znane ukrepe, načine in sredstva za uravnavanje rodnosti (sterilizacija in oploditev z biomedicinsko pomočjo).

K sprejetju zakonodaje leta 1977 je botrovalo več dejavnikov: ugodna politična klima, liberalizacija javnosti do tega vprašanja (ki je verjetno del kompleksnejših liberalnih stališč do življenjskih, socialnih in političnih vprašanj), visoka podpora žensk do pravice do umetne prekinitve noseč- 
nosti ter osebna angažiranost velikega števila slovenskih strokovnjakov in strokovnjakinj z različnih področij delovanja.

Zakon je dobil potrditev tudi v 55. členu nove slovenske ustave iz leta 1991. Odločitev o umetni prekinitvi nosečnosti je torej pri nas z ustavo zagotovljena pravica ženske, ki zanosi, a ne želi (noče) roditi. Zakon ji daje to pravico ne glede na dejstvo, da je prekinitev nosečnosti zdravstveno in socialno neželen ukrep oziroma izhod v sili. Naša pravna ureditev umetne prekinitve nosečnosti je ena tistih, ki ženski priznava pravico, da z umetno prekinitvijo nosečnosti uravnava rojevanje.

$\mathrm{Na}$ število umetnih prekinitev nosečnosti vpliva več dejavnikov, od kvalitete spolne vzgoje v procesu izobraževanja do skrbi države za izobrazbo žensk o varnih metodah kontracepcije. Postopne liberalizacije predpisov $\mathrm{v}$ zvezi z umetno prekinitvijo nosečnosti v nekdanji Jugoslaviji ni povsod spremljala intenzivna akcija za prevencijo, zato se je v nekaterih republikah povečalo število ne le legalnih, ampak tudi ilegalnih splavov.

Ocena dela na področju reproduktivnega zdravja žensk pri nas od petdesetih let dalje kaže, da je bilo vloženega veliko truda, da bi sistematično delovali na vseh ravneh, ki pripomorejo $\mathrm{k}$ izboljšanju zdravja populacije v rodnem obdobju: uvajanje spolnoizobraževalnih vsebin v vzgojno-izobraževalne programe, promoviranje in izobraževanje o uporabi kontracepcijskih metod kot sredstev za preprečitev nezaželene nosečnosti ter ustanavljanje dispanzerjev za ženske in posebnih kontracepcijskih svetovalnic. Kljub temu je bilo stanje marsikje še vedno nezadovoljivo (upoštevaje ekonomsko razvitost in navsezadnje tudi neenako pripravljenost odgovornih za reševanje tega vprašanja). Zakonski predpisi niso mogli preseči kulturnih praks in globoko zakoreninjene tradicije, še posebej na bolj ruralnih območjih. Stopnja maternalne umrljivosti, mrtvorojenosti in splavov je bila pri mladoletnicah še vedno visoka, preventivna vzgoja je delovala neustrezno, informiranja o kontracepciji oziroma njene predstavitve v medijih pa tako rekoč ni bilo.

M. Šircelj $(2006,175)$ ugotavlja, da se je v Sloveniji po sprejetju zakona iz leta 1977, ko je bila umetna prekinitev nosečnosti dovoljena izključno na zahtevo nosečnice, pogostost dovoljenih splavov res povečala, vendar le pri posebnih skupinah prebivalstva, in to le za določen čas. Rodnost je 
ostala enaka; med mladimi se je še nekaj let povečevala, med starejšimi pa še naprej zniževala.

Zelo malo ljudi se ne bi strinjalo s politiko javnega zdravstva preprečevanja nezaželenih nosečnosti z modernimi sredstvi kontracepcije in zmanjševanjem števila postopkov umetne prekinitve nosečnosti ter $\mathrm{z}$ zagotovilom, da se večina teh postopkov opravi v prvih treh mesecih nosečnosti, ko je to za žensko najvarneje. Videti je, da stopnja ozaveščenosti, da je splav družbena realnost in da se ga ne da zaobiti in preprečiti s kakršno koli zakonodajo, narašča. Zgodovina nekaterih držav nam je $\mathrm{z}$ usodo stotisočih žensk pokazala, da zaostritev pogojev za dostopnost do splava števila splavov ne zmanjša, temveč splav zgolj potisne $v$ ilegalo.

\section{LITERATURA}

Andoljšek, L. in drugi, Vpliv ginekologov na razvoj načrtovanja družine v Sloveniji, v: ABORTUS - pravica do izbire?!: pravni, medicinski, sociološki, moralni in politični vidiki (ur. Bahovec, D. E.), Ljubljana 1991, str. 191-196.

Besemeres, F. J., Socialist population politics: The political implications of demographic trends in the USSR and Eastern Europe, New York 1980.

Budna Kodrič, N., Feministične zahteve, v: Splošno žensko društvo: 19011945 (ur. Budna Kodrič, N. in Serše, A.), Ljubljana 2003, str. 35-43.

David, P. H., From Abortion to Contraception: A resource to Public Policies and Reproductive Behavior in Central and Eastern Europe from 1917 to the Present, London 1999.

Geč-Korošec, M., Družinsko pravo SFRJ, 1. del, Ljubljana 1981.

Geč-Korošec, M., Družinsko pravo SFRJ, 2. del, Ljubljana 1984.

Jeraj, M., Slovenske ženska društva med obema vojnama (1918-1941), Arhivi XXII, 2, str. 53-61.

Jeraj, M., Angela Vode, v: Splošno žensko društvo: 1901-1945 (ur. Budna Kodrič, N. in Serše, A.), Ljubljana 2003, str. 166-187. 
Krajnc-Simoneti, S., Zdravstveno varstvo žena v SR Sloveniji v letih 19691979, Ljubljana 1981.

Maček, M., Pravni vidiki umetne prekinitve nosečnosti v Sloveniji, v: Umetna prekinitev nosečnosti v Sloveniji (Pinter, B. in Pretnar-Darovec, A.), Ljubljana 2004, str. 29-33.

Meden-Vrtovec, H., Akademikinja Lidija Andoljšek-Jeras: Ženska za ženske, v: Umetna prekinitev nosečnosti v Sloveniji (Pinter, B. in Pretnar-Darovec, A.), Ljubljana 2004, str. 3-5.

Obersnel Kveder, D. in drugi, Trideset let načrtovanja družine - naložba v varno materinstvo, Zdravstveno varstvo 1998, 37, str. 87-93.

Rožman, I., Spolno življenje in kultura rojstva na Dolenjskem od 2. polovice 19. stoletja do 2. svetovne vojne, Doktorska disertacija, Ljubljana, Filozofska fakulteta 2001.

Serše, A., Ana Zalokar, v: Splošno žensko društvo: 1901-1945 (ur. Budna Kodrič, N. in Serše, A.), Ljubljana 2003, str. 248-255.

Simoneti Krajnc, S. in drugi, Law and fertility in Yugoslavia, v: Law and fertility in Europe, 1976, 2, str, 665-693.

Simoneti Krajnc, S., O razvoju dispanzerjev za ženske, v: Kako smo dosegli, da nam dojenčki ne umirajo več. Simpozij v počastitev 70-letnice akad. prof. dr. Lidije Andolšek-Jeras, Ljubljana 1999, str. 29-30.

Stloukal, L., Understanding the "Abortion Culture" in Central Eastern Europe, v: From Abortion to Contraception (ur. David, P. H.), Westport 1999, str. 23-38.

Šircelj, M., Rodnost v Sloveniji od 18. do 21. stoletja, Ljubljana 2006.

Takač, I., Pol stoletja načrtovanja družine v Mariboru, v: 50 let načrtovanja družine v Mariboru: mednarodni znanstveni simpozij, Univerzitetni klinični center Maribor, 15. 6. 2007 (ur. Takač, I.), Maribor 2007, str. 31-178.

Tomšič, V., Ženska, delo, družina, družba, Ljubljana 1976.

Tomšič, V., Komunistična partija Jugoslavije v boju za emancipacijo žensk, Ljubljana 1978.

Tomšič, V., Izbrani teksti I, Ljubljana 1980. 
Vode, A., Spol in upor. Zbrana dela Angele Vode, 1. knjiga, Ljubljana 1998. Zajc, M., Kriki in šepetanja, v: ABORTUS - pravica do izbire?!: pravni, medicinski, sociološki, moralni in politični vidiki (ur. Bahovec, D. E.), Ljubljana 1991, str. 31-39.

\section{VIRI}

Andoljšek, L., Za uresničevanje pravice do svobodnega odločanja o rojstvih otrok, Naša žena, marec 1976.

AS 1413, osebni fond Vida Tomšič, Arhiv Republike Slovenije.

Navodilo za izvrševanje Uredbe o pogojih in postopku za dovolitev splava. Ur. l. FLRJ, št. 52/1960.

Pantić Starič, N., Prof. dr. Franc Novak, Naša žena, januar 1973.

Puhar, A., Burne razprave, Delo, 5. oktober 1973.

Resolucija o planiranju družine. Ur. 1. SFRJ, št. 20/1969, leto XXV, (8.5.1969).

Resolucija o načrtovanju družine in družbenih prizadevanjih za njen nastanek in varnost. Ur. l. SRS, št. 18/1974, leto XXX (10.5.1974).

Splošni zakon o prekinitvi nosečnosti. Ur. 1. SFRJ, št. 20/1969, leto XXV (8.8.1969).

Tomšič, V., Ali je legalizacija splava sprejemljiva rešitev, Borba, 17. januar 1954.

Uredba o postopku za dovoljeno odpravo plodu. Ur. l. FLRJ, št. 4/1952 (19.1.1952).

Uredba o pogojih in postopku za dovolitev splava. Ur. l. FLRJ, št. 9/1960.

Ustava Socialistične republike Slovenije. Ur. l. SRS, št. 6/1974 (25.2.1974).

Zakon o pogojih in postopku za prekinitev nosečnosti. Sl. 1. SR BiH, št. 29/77.

Zakon o pogojih in postopku za prekinitev nosečnosti. Sl. l. SRS, št. 26/77. 
Zakon o pogojih in postopku za odobritev prekinitve nosečnosti. Sl. 1. SAPK, št. 47/77.

Zakon o pogojih in postopku za odobritev prekinitve nosečnosti. Sl. 1. SAPV, št. 26/78.

Zakon o pogojih in postopku za prekinitev nosečnosti. Sl. l. SR ČG, št. $29 / 79$.

Zakon o prekinitvi nosečnosti. Sl. glasnik na SRM, št. 19/79.

Zakon o zdravstvenih ukrepih za uresničevanje pravice do svobodnega odločanja o rojstvu otrok. Nar. novine, št. 18/78.

Zakon o zdravstvenih ukrepih pri uresničevanju pravice do svobodnega odločanja o rojstvu otrok. Ur. l. SRS, št. 11/1977 (19.5.1977).

Zdravstveni statistični letopis 2002 (2003). Inštitut za varovanje zdravja Republike Slovenije, Ljubljana. 


\section{THE GENESIS OF POLITICAL THOUGHT REGARDING VOLUNTARY INTERRUPTION OF PREGNANCY IN THE FORMER YUGOSLAVIA}

Keywords: voluntary interruption of pregnancy, family planning, liberalization of legislation, constitutional right

\section{Abstract}

This article focuses on the genesis of political thought regarding voluntary interruption of pregnancy (VIP) in the former Yugoslavia, with particular emphasis on the shaping of Slovenian legislation. The article demonstrates that the laws regulating VIP in the former Yugoslavia were liberalized gradually and cautiously. The constitutional principle of freedom of choice regarding childbirth, dating back to 1974, became the foundation for approving the Slovenian legislation in 1977, which is now considered some of the most liberal in this area. At the same time as the approval of this legislation, family-planning programs began coming into effect. Promoting the concept of family planning has been a great investment because these programs offered appropriate information on family-planning principles, the use of modern contraception, and means of detecting and treating sterility. 